Chinese Sociological Review, vol. 45, no. 2, Winter 2012-13, pp. - .

(C) 2012 M.E. Sharpe, Inc. All rights reserved. Permissions: www.copyright.com

ISSN 2162-0555 (print)/2162-0563 (online)

DOI: $10.2753 / C S A 2162-05554502$

\title{
Elite Christianity and Spiritual Nationalism
}

Nanlai Cao, Hong Kong Institute for the Humanities and Social Sciences, University of Hong Kong and Renmin University of China

\begin{abstract}
This paper explores the intersection of spiritual renewal and grassroots nationalism within contemporary Chinese Christianity through the case of Wenzhou's boss Christians - an emerging group of Christian businessmen who have spearheaded the growth of independent churches in the coastal Wenzhou area. Prompted by their success in the new entrepreneurial world, these elite male Christians strive to gain spiritual prestige and moral superiority in the Chinese church by employing a spiritual narrative of their post-Mao economic success and by articulating and spreading a new vision that they call "God's China vision." In active response to the Chinese state's nationalist discourse of modernity, they are convinced that China will rise not only in the economic sphere but also in the spiritual realm and will transform from a missionary receiving country to a missionary sending one. The paper links this grassroots project of spiritual nationalism to a redemptive process in which elite Chinese Christians seek to address and overcome victimization and suffering inflicted by secular state modernity. It concludes that post-Mao Christian development has come to be closely connected to national memories and nationalist imagination, countering the party-state's insistence on secular nationalism.
\end{abstract}

\section{Grounding China’s Christianity in Divergent Social and Geographical Locations}


Since the expulsion of foreign missionaries by the new Communist regime in the early 1950s, (Protestant) Christianity has been thoroughly indigenized through close contact with immediate local Chinese realities. The absence of an overarching central interpretative authority has contributed to the hybrid and fragmented nature of contemporary Chinese Christianity (Dunch 2001a). Pentecostalism as a highly emotional form of religiosity appears to be the dominant form of Christian expression among organizationally independent house church groups operating outside the officially controlled Three-Self Patriotic Movement (TSPM) church system (Wesley 2004). ${ }^{1}$ This is mainly a result of Pentecostalism's ability to adapt to diverse, changing local circumstances and to address daily practical concerns of differentially positioned people. This paper explores the interlinked phenomena of Pentecostal-influenced urban Christian revival and rising nationalist emotions at the grassroots in the postreform context of China's modernization and globalization. I use the term "spiritual nationalism” to capture the multilayered process in which advantaged urban Chinese Christians internalize nation state norms, fashion themselves as modern religious subjects compatible with the nation-building project, and adapt and contribute to the rise of nationalism from below. ${ }^{2}$ A discussion of the different patterns of church growth in contemporary China will inform my analysis of spiritual nationalism that is implicit in the practices of some elite Christian businessmen in coastal China. It will become clear that this spiritual nationalism of elite Chinese Christians resonates with the notion of China as a Christian Republic popular among early revolutionaries and urban professionals, who were under tremendous Western missionary influence at the turn of the twentieth century and who drew on Western Protestant notions of nationalism in their struggle to build a modern Chinese nation state (see Dunch 2001b; Goossaert and Palmer 2011, 68-73). However, this is not to suggest that Christianity is intrinsically linked to elite Chinese nationalism, but rather that Christians’ nationalist claims mark an elite form of religiosity in contemporary China. 
Furthermore, as this study will show, rather than being hegemonic and monolithic, the stateled nationalist project creates a discursive space for the emergence of this alternative, grassroots version of nationalism that is not antithetic to local and regional identities in China’s peripheral coastal regions.

China has witnessed a dramatic revival of Christianity in the last few decades of economic reform. Recent estimates of the Chinese Christian population range from 23 to 60 million (Aikman 2003; Jin and Qiu 2010). Although the Christianity fever has swept across the country, there are regional variations in the pattern of church growth, compounded by the differentiation between the official TSPM churches and the so-called house church movement. Generally, the many rural-based house churches feature a charismatic structure dominated by illiterate or semi-illiterate, experientially inclined lay women, while the TSPM movement in urban, metropolitan areas has an institutionalized structure in which theologically trained male clergy assume leadership positions. ${ }^{3}$ This experiential/theological split continues to play out in the process of intensified urbanization, and the Christian scene is far more complex and varied at the grassroots level.

Even though religious persecution is often harshest in the impoverished inland, the rural inland provinces such as Henan and Anhui have the fastest growth rates of charismatic or Pentecostal-like house churches. The spectacular growth has to a large extent depended on a multitude of traveling revival preachers and fluid, horizontal Pentecostal church networks that the state cannot effectively control and monitor. Charismatic leaders of the rural house church often draw on their experiences of suffering under oppression and hardship and embrace an identity of martyrdom. These church communities take a spiritual approach to social and political issues and are exclusivist in orientation. Low level of education, minimally trained clergy, lack of medical provision, and rural poverty all seem to have contributed to the Pentecostal/charismatic tendency in the countryside. 
This rural, anti-institutional, charismatic sentiment is not shared by the newly emerged house churches in major Chinese cities like Beijing where there is a significant portion of university-educated intellectuals, academics, and other members of the urban middle class involved in church activities. These often Western-oriented or more specifically Anglo-America-oriented house churches focus on the study of Christian doctrines and actively engage in the public discourse on human rights with a focus on the religious rights of house Christians (Wielander 2009). Led by some prominent liberal intellectuals and rights lawyers with the ultimate vision of a Christian China, high profile Beijing house churches represent the most organized and politically active sector of the Chinese house church community. It is not an exaggeration to say that a much politicized intellectual house church movement has taken shape in the capital city under close monitoring and scrutiny by the central party-state.

The prosperous coastal city of Wenzhou in southeast China produces another distinctive regional model of church development in the reform era in which the new rich businessmen, locally called “boss Christians,” spearhead the revival. ${ }^{4}$ Wenzhou’s recent Christian revival has benefitted from the city’s political marginality and a mission-derived local faith tradition as well as a vibrant household economy. It is now the most Christianized Chinese city with a Christian population estimated to be as many as one million. This upwardly mobile class of Christians, usually with rural origins, has a separate identity from either the official TSPM church, rural house church groups, or Beijing's intellectual house churches. Many Wenzhou churches are headed by the boss Christians and are informally recognized by but not officially registered with the local state. Although not affiliated with the TSPM or any other official organizations, they operate aboveground and develop activities and programs outside the boundaries of the traditional house church. This type of independent house church is among the fastest growing of all newly founded Christian 
churches in the area. As this entrepreneurial city is in the midst of rapid rural industrialization and urbanization, most local churches have a recognizable rural Pentecostal and charismatic origin, as shown in the emotional style of worship and the staging of spirit-filled revival meetings focused on faith healing.

Although urban-oriented modern Chinese Christians increasingly emphasize the systematic study of theology and a hierarchical, professionalized structure of church management, the established rural-based Pentecostal tradition continues to inform Chinese Christian development at the turn of the new century and has been revived and strengthened from the 1980s on by clandestine evangelical activities of overseas Pentecostal missionaries in China as well as by the introduction of Pentecostal teachings from Chinese-speaking East and Southeast Asia. ${ }^{5}$ As China’s pace of urbanization accelerates, some rural Pentecostal networks have also migrated to cities or been absorbed into newly urbanized areas. The Pentecostal energy has taken new forms in the evolving urban Chinese Christian community. Rapid urbanization of the countryside has blurred the line between the rural and the urban and between the premodern and the modern, and resulted in a new synthesis of the social religious order. In the boom city of Wenzhou a new wave of theology-minded entrepreneur church leaders and preachers interact with emotion-filled charismatic Christian women both within and outside the church. Although a textually based, theology-driven Christianity has developed in dynamic interaction with an emergent capitalist regional economy in China's advanced coastal regions, this elite mode of Christianity constantly manifests a Pentecostal sentiment, contributing to the growth of the charismatic sector of post-Mao Chinese Christianity.

While recent Christian revival has evidently benefited from the relaxation of state control over religion as well as economic and social reforms in the post-Mao era, the exponential growth of Christianity most likely started much earlier than commonly believed. 
This is particularly true if we take into account the fast-growing Pentecostal subcurrent. A closer examination reveals historical links between post-Mao Christian revival and the development of an independent, Pentecostal sector of Chinese Christianity a century ago. ${ }^{6}$ The Pentecostal sector strengthened and expanded the appeal of the imported Christian faith in the early twentieth century. It might be argued that early indigenous Pentecostal preachers and networks, often with strong nationalist tendency, formed the prototype of Chinese Christianity that continues to inspire later generations of Chinese Christian leaders. The following analysis details the development of an indigenous Pentecostal movement with emphasis on its historical dimension.

\section{Indigenization and Spiritual Revival}

For the most part of the twentieth century, Christianity has been viewed as a foreign religion (yangjiao) in Chinese society. The popular aphorism "One more Christian, one less Chinese” denotes this essential foreignness of Christianity in China. The anti-Christian sentiment is deeply rooted among China’s urban political and cultural elites since the May Fourth Movement of 1919 that rejected all religions as superstition and subsequently triggered a series of anti-Christian movements (Lutz 1988). Until the 1980s, many Chinese intellectuals had considered Christianity a cultural agent of Western imperialism. However, the rapid growth of independent Pentecostal-style Chinese church groups in the early twentieth century showed us the alternative picture of an indigenous Chinese spiritual revival. As a model of spiritual renewal emphasizing miracles and wonders, Pentecostalism has been an integral and permanent feature of Chinese Christianity since the turn of the twentieth century. Early Chinese Pentecostal leaders, with their nationalistic feelings and their longing for direct, unmediated access to divine power, pushed Chinese Christianity to break away from foreign control and spread across the vast rural hinterland. Its noninstitutional character, millenarian belief, and ability to absorb folk religious and cultural elements enabled the Pentecostal 
influenced rural church to survive persecution during the Maoist decades and flourish in the reform era. Inspired by Western Pentecostal teachings, Chinese revival preachers in the first half of the twentieth century led an indigenous revival movement whose influence can still be felt in today's Chinese churches, especially in the rural inland. These early Pentecostal groups and networks informed the organization of the later house church movement that, in my view, ought to be understood not in terms of an explicit antistate or anti-TSPM agenda but in terms of their shared charismatic leadership.

In the 1920s and 1930s, the Chinese church underwent indigenization and revival simultaneously. In rural provinces such as Henan, Anhui, Shandong, and Hunan, Pentecostal worship has been practiced in local congregations and homes under the influence of several nationally known charismatic Chinese evangelists (Hunter and Chan 1993). Notable among them were John Song and Watchman Nee (see Lee 2005). Echoing anti-Western, antiimperialist emotions prevalent at the time, these native evangelists were known for their antagonism toward foreign mission churches and their strong determination to build an independent Chinese church (Bays 1993; Deng 2005). Paradoxically, they were often brought up in the missionary context and had close contact with Western Pentecostal missionaries who came to China in the wake of the Azusa Street Revival of 1906.

These native revival preachers were mostly charismatic-oriented and held an eschatological belief in the second coming of Christ. Their evangelistic work, usually in the form of large meetings involving spiritual renewal and healing, proved to be remarkably successful. These revival meetings have been described by Alan Hunter and Kim-Kwong Chan:

Some were calm, peaceful and serious, with an intense spiritual atmosphere. Others were more lively, addressed by fierce speakers. Special stress was laid upon the deadly power of personal sin, with the result that large numbers of listeners were 
moved with strong conviction of guilt and the desire to repent. Public confession was emphasized and others heard hundreds of private confessions in the course of their revivals. Some preachers go to the extreme in noisy, dramatic, sensational and Sundayesque preaching, outdoing even their prototype in startling and unique features (Hunter and Chan 1993, 129).

These traveling native preachers played a major role in the formation of the conservative spiritual tradition of the Chinese church. Accordingly, some nationwide indigenous Chinese Pentecostal groups emerged in the 1920s and 1930s, including the True Jesus Church, the Jesus Family, and the Little Flock (known also as Local Assemblies) (Bays 1995; Lee 2005; Lian 2010). They can all be characterized by personal charismatic leadership, a fundamentalist view of the Bible, a separatist tendency, and active involvement of women. All of them resurfaced after the Cultural Revolution. The True Jesus Church was the largest indigenous Pentecostal group in the first half of the twentieth century (see Bays 1995; Deng 2005). Today it is estimated to have one million members scattered across southern and eastern China (Deng 2005, 449). $<<$ Page 449 is outside the range provided in the reference. Fix the citation or reference. Reference fixed $>>$

In an attempt to explain this Pentecostal growth, church historians have observed the natural affinity between Chinese sectarian religion and the Pentecostal emphasis on healing, divine revelations, and millenarianism. For example, Daniel Bays has pointed out some parallel themes between the True Jesus Church and the sectarian White Lotus tradition. He notes that when Pentecostal Christianity was first brought into China by Western missionaries in early twentieth century, "the new elements of the Christian Pentecostal message may have been more effective bridges to certain parts of traditional Chinese society than had been the nineteen-century Christian message” (Bays 1995, 139). Gotthard Oblau went further to suggest that contemporary Chinese Christianity bears inherent Pentecostal characteristics and 
can thus be viewed as "Pentecostal by default" (as he put it in the title of his essay) (Oblau 2005). It seems that Pentecostalism furnished a flexible religious milieu in which indigenous Chinese preachers were able to creatively adapt Western-imported Christianity to the folk Chinese mode of religiosity and express a strong nationalistic sentiment. This Pentecostal paradigm provides a vantage point for understanding the dynamics of Christian growth in China.

Owing to its resemblance to superstitious elements that characterize Chinese folk religion, Pentecostal/charismatic Christian practices such as spiritual healing and performing miracles are subjected to negative labeling by both the state and the state-controlled churches in the reform era. Various antisuperstition campaigns and the recent crackdown against heretical sects (especially Falungong) have contributed to a serious stigma associated with charismatic phenomena in society. ${ }^{7}$ State-approved clergy publicly disapprove of the miraculous mode of the religion, especially the Pentecostal style of healing meetings that continue to draw huge crowds in southeast China today (En 2005). For many believers and Christian scholars affiliated with the TSPM, a by-product of such a dynamic and diverse Pentecostal revival is the emergence of various Christian-inspired heretical sects or new religious movements that often manifest a strong folk religious flavor. These are the heterodox offshoots of Chinese Pentecostalism. The most well-known case is the East Lightning. Emerging in Henan in the early 1990s, East Lightning proclaims a belief in the "female Christ” and uses intimidation and violence to recruit converts. ${ }^{8}$ The group has been labeled by the Chinese government as an "evil cult” and officially banned. Both the TSPM and major house church networks are wary of such groups and publicly denounced them as heterodox. Leaders of the major house church networks in Henan have taken action to distant themselves from these groups for fear of state suppression (Madsen 2010). In 1998, these leaders $<<$ Change correct?yes $>>$ signed and issued a "Statement of Faith" to assert the 
authenticity of their Christian faith. By declaring their belief in the gifts of the Holy Spirit and miracles in the present world, the statement unintendedly exposed these house churches' Pentecostal theological orientation to the public for the first time (Wesley 2004).

As it often draws on popular cultural resources in local communities, Pentecostalinfluenced Chinese Christianity has contributed to the spreading of indigenous church networks and become almost the ideal type of grassroots Christianity in rural China (Lian 2010). Even in the Mao era, harsh repression of religious activities was unable to eradicate this noninstitutional form of Christianity. In fact, political repression restructured Christianity from a nontraditional religion into a female-dominated Pentecostal-style Christianity thriving within the rural cultural framework of popular supernaturalism (Kao 2009). It is important to note that this indigenization has much to do with the charismatic power of many rural Christian women who actively engage in the practices of healing and exorcism during and after the Maoist decades. This female-centered, individualized experiential religiosity was far more dynamic (partly owing to its low public visibility and thus its ability to escape official scrutiny) than the earlier mission-founded Christianity and greatly facilitated Christian breakthroughs during the Cultural Revolution. Till the 1980s, Chinese Christianity became largely a rural indigenous Pentecostal phenomenon and an overwhelmingly female institution. Given the serious shortage of trained clergy and the lack of institutionalized structures, the Pentecostal impulse in rural Christian communities can hardly be contained or tamed within the boundaries defined by officially approved Christianity.

Despite the popular image of Chinese Christianity as a disadvantaged female institution in the rural inland, more and more Chinese urban elites are turning to Christianity because they identify it with the world's greatest modern industrial success. While both intellectual house churchgoers in Beijing and Christian business elites in coastal areas consciously position Christianity as a civilizing and moralizing force in Chinese society, rural 
Christian women with their charismatic beliefs and practices are often placed in a position antithetic to an evangelical textually oriented Christianity that has been perceived as the only correct faith in the eyes of many urban Christian elites. Rural women-dominated Pentecostal/charismatic Christianity is deemed inferior for its tendency to develop highly syncretistic and communally embedded practices and its lack of ability to maintain transnational connections, real or imagined. When charismatic-oriented rural women move into the city, they find themselves being placed on a continuum from backwardness to modernity. Although their contribution to the church is publicly acknowledged, their Pentecostal energy is often scrutinized and controlled by the values of the new entrepreneurial and professional class of believers.

In the last quarter of the twentieth century, $<<$ Change correct?yes $>>$ Wenzhou has become the largest urban Chinese Christian center, known as “China’s Jerusalem.” The reform-era revival of Wenzhou Christianity has accompanied the city’s dynamic industrialization and modernization process and is led by a new entrepreneurial class of male believers. However, Wenzhou used to be a rural town that sent a great number of migrant workers and peddlers to the rural inland. Two decades ago, Wenzhou churches were mostly charismatically oriented, as is the case in rural Henan and Anhui today. Today, there is still a strong charismatic tendency among Wenzhou Christian women, but most local Christian men identify themselves as fundamentalists or evangelicals and embrace textually centered church activities such as theological study and publication ministry—a very recent phenomenon mainly owing to the rise of a rationalized modernity as well as the ideal of elite masculinity in reform-era coastal regions (Cao 2009). A majority of Wenzhou Christian businesspeople today were born into a local faith tradition derived from the early Western missionary enterprise in the region. 
While the Catholic Church in pre-1949 China was largely controlled by Western missions, three of the six Protestant Christian denominations (or mission groups) in pre-1949 Wenzhou were founded by local Chinese Christian leaders, independent of foreign missions. In a sense, the current Wenzhou entrepreneur-led Christian development can be seen as a successor to the pre-1949 Wenzhou church movement in terms of stressing local Christian leadership and indigenization of the church. After China's economic reforms began in the late 1970s, Wenzhou Christian entrepreneurs become suddenly rich through production and trade. After getting rich, they became increasingly attached to the Christian community because they considered their business success a direct result of God's blessing for Wenzhou's Christian tradition and their Christian family background. The popular notion of supernatural causality directs many loosely committed entrepreneur Christians to the Bible for meaning and subsequently fuels their passion for evangelization. Through the popular rhetoric of “redeeming God’s blessing,” local church leaders are able to mobilize resources and energies from even formerly half-hearted Christian businesspeople to support a variety of church work, but mainly church building and planting.

\section{The Missionary and Nationalist Impulses of Elite Businessmen: The Contemporary}

\section{Wenzhou Case}

The growth of Pentecostal/Charismatic Christianity in the reform era helps reconcile the conservative spiritual tradition of the Chinese church formed in the early twentieth century with utopian dreams of capitalist success that are so prevalent in today's China. As members of the local business elite, the Wenzhou boss Christians often present themselves as God's steward and consider their financial contributions to the church as investment in God's miracles. They stress that doing business is serving God and that without a private enterprise one would not be able to do good work in the church. Ordinary churchgoers are well aware that private bosses are resourceful and capable individuals who are in a better position than 
nonboss lay leaders to help develop the church, especially when the church faces state pressure.

There is no statistical information available on the percentage of Christians among the broader population of private entrepreneurs in Wenzhou. Given the estimated total Christian population $(1,000,000)$ and the percentage of private entrepreneurs and merchants (5 per cent) in Wenzhou (Wenzhou Bureau of Statistics 2005), $<<$ Change correct? See the reference. $>>$ my estimate is there are around 50,000 major Christian entrepreneurs and merchants. If we take into account relatives and friends who work for family enterprises and white collar employees with wealth who also fall in the "boss" category, the figure would be much higher. Although Christian identity may not be essential for a Wenzhou entrepreneur to conduct his business, it would certainly constitute a great advantage when networking with Christian business partners locally, nationally, and even transnationally. In the business world, Christian entrepreneurs not only represent themselves as more trustworthy (through their Christian moral discourse) than their non-Christian counterparts, but also can mobilize their church networks that are not accessible to non-Christians.

These Christian businessmen have forged new notions of wealth and power in the local church by channeling commercial wealth into various church projects. Local boss preachers often quote John Wesley, a key figure in the evangelical revival of eighteenthcentury England who contributed to forming the prosperity doctrine of Pentecostalism, urging Christian entrepreneurs to "make all you can, save all you can, and give all you can.” Such teachings place the most emphasis on one’s entrepreneurial productivity and echo China’s reformist leader Deng Xiaoping’s slogans of “building socialist market economy with Chinese characteristics” and "poverty is not socialism” in ideologically liberating terms, unleashing personal economic ambitions that were severely suppressed in the Maoist era. 
In response to state repression and dramatic socioeconomic change, China’s Catholics tend to develop closely knit faith communities and an isolationist mentality even after the state adopted a more tolerant and pragmatic approach to religion (Madsen 1998). In contrast, these elite Christian businessmen are willing to integrate their religion into mainstream political economic developments in the post-Mao reform era, although they may have to face sporadic state persecution for developing unregistered church spaces and activities. ${ }^{9}$ To deal with the marginalization of Christianity by the atheist state, elite Christian businessmen have embraced nationalist ideology and market modernity in the church context.

\section{Understanding the Spiritual Significance of Post-Mao Success in a Nationalist Manner}

The rise of the entrepreneurial and professional class of Christians has largely moderated the female-centered Pentecostal Christianity, especially in curbing its desire for emotion-filled meetings. As a volunteer reporter for the Christian entrepreneurs’ fellowship between 2005 and 2006, I had the privilege of observing a transition of charismatic leadership from inside. I had access to some internal documents circulated among a small circle of lay leaders. I sat through many planning meetings and was able to oversee various projects and activities from inception to completion. I also made numerous short field trips to Wenzhou from 2008-2012 to conduct follow-up interviews. These elite male Christians appreciate the spiritual help from the older generation of church workers, including laywomen, but refuse to submit to their charismatic authority in the church. They strive to gain spiritual prestige and moral superiority through spiritualizing their economic success and elevating the status of Wenzhou as a regional center of the world mission. As many Wenzhou bosses attribute their own economic success and Wenzhou's rapid development in the reform era to the work of the Holy Spirit, $<<$ If you want to retain the quotes, supply their sources. No, this is fine $>>$ they also express the hope of depending on the power of the Holy Spirit to let China become the world's blessing. This is, in one boss Christian's words, an alternative force to help China 
rise. There is a dynamic relationship between emotional nationalism and Pentecostal influence among the elite Wenzhou Christian men I have worked with. It will soon become clear that, on the one hand, these men use Pentecostalism as a handy method to express powerful nationalistic sentiment. On the other hand, they employ nationalistic visions to construct their charismatic authority in the context of a postsocialist Chinese modernity.

Prompted by their success in the new entrepreneurial world, some boss Christians have started to fashion themselves as part of a new generation of charismatic leaders in the Chinese church by articulating and spreading a new vision that they call “God’s China vision” (zhongguo yixiang). Those who share the vision agree that China will rise not only in the economic sphere but also in the spiritual realm. As Brother Jian put it, characteristically, The international community is paying great attention to China. To look at the GDP, China is now the second largest economy. In the spiritual field China may take the last baton in the global evangelical movement. But China needs to be renewed and transformed first. Some individuals must rise to lead the revival. Based on my personal experience, I feel the most important thing is to have spiritual release and healing and to have a renewed purpose in life. To have (spiritual) influence on society one must pursue a (business) career.

To secure and confirm the Wenzhou church's leadership role in the Chinese evangelical enterprise, many seek to borrow legitimacy and acquire influence from the old Western Christian civilizing project. Some refer to the Western missionary experience in China as part of the reason why they now should strive arduously to fulfill this God's China vision so as to “repay the gospel debts” (huan fuyin zhai) to those Western missionaries who died in China a century ago. The typical expression is usually put in a rhetoric question: "Those foreigners even have such a burden for China, how about us? How should we act?” One figure they often cite in speeches and sermons is Reverand J. Hudson Taylor (1832-1905), a British 
missionary who founded the China Inland Mission. His often-quoted statement was, "If I had a thousand pounds, China should have it. If I had a thousand lives, China should have them.”10 Interestingly, I have heard no one mentioning the last part of Taylor's statement, “No! Not China, but Christ. Can we do too much for Him? Can we do enough for such a precious Saviour?” As the partial quote shows, the manipulative use of Western missionary references is a deliberate effort to promote the China vision among the local Christian community.

The dream about a Christianized China is also embodied in the singing of a Chinese hymn titled China's Mission (xuanjiao de zhongguo) that Wenzhou Christian bosses are particularly fond of. They would like to sing it over and over again in various church meetings. The lyrics go like this, "I walk forward with a mission, to wake up a sleeping China, we won’t turn around even when shedding blood. I walk forward with a vision to see an evangelistic China and spread the Gospel to every corner of the world ... one day China will rise, one day China will rise, break the closed door and the solid barracks, let the evangelical flag wave in China, let the church be united.” The strong sense of mission permeates their narratives and forms their exclusive claim to leadership in world Christianity. This is a clear reflection of their intense desire to compete with the West and to achieve elite status in global Christianity by exporting the Gospel to other parts of the world. It seems that elite Chinese Christians charismatically perform an evangelical identity to overcome a sense of marginalization in the global Christian movement in which Chinese Christians have always been treated as victims of the atheist Communist state.

\section{Using National Glory and Nationalist Imagination to Promote a Global Chinese Mission}

The charismatic insistence on spiritualizing economic modernization and development contributes to a strong impetus toward evangelization in less developed regions. As a way of redeeming the divine blessing and showing the spiritual and moral significance of economic 
success, many businessmen-led Wenzhou churches have sent evangelical teams to the rural inland and the impoverished ethnic minority regions in southwest China. However, the ultimate goal of the China vision is for the Chinese to evangelize the Muslim nations in the Middle East and eventually bring the Gospel back to Jerusalem. ${ }^{11}$ Although the "Back to Jerusalem Movement” has incurred criticism from some China ministries in the West for being a scam, today in the Chinese church, many people believe that the Gospel came from Jerusalem and it must also be brought back to Jerusalem eventually. In their narratives, this is like running a relay race in which different countries and peoples in different periods play different roles in this great mission of evangelizing the globe. Because of the perception of China's rising political economic power and global influence, many Wenzhou Christian bosses deeply believe that now it is the Chinese turn to undertake the great mission of returning the Gospel to Jerusalem and that China will take over the last relay baton in this race in Asia (see Nyíri 2006). One Christian boss, for example, listed four recent great events (shengshi) that portray China's flourishing age when explaining why China should be the most qualified country in carrying out this God's plan. ${ }^{12}$ These events and moments of national glory include China’s entry to the World Trade Organization, Beijing Olympic, Shanghai World Expo, and the successful launch of the Shenzhou VI manned spacecraft. Moreover, the Christian bosses also repeatedly bring up the Wenzhou church’s status as the first urban church in China and the title of Wenzhou as “China’s Jerusalem” to argue that Wenzhou is destined to play the leadership role in this global relay race of evangelization. The metaphor of the relay race involves not just collaboration and coordination but more importantly global competition.

Overseas Chinese Christians have lent tremendous power and legitimacy to Wenzhou Christian entrepreneurs in promoting the vision of taking the last relay baton of the world mission. During my fieldwork I followed a small group of Wenzhou Christian businessmen 
to attend a Christian entrepreneurs' conference in a four-star resort hotel in coastal Guangdong Province. What struck me the most at the three-day conference entitled “Business as Mission” (jingshang jiushi shifeng) was a pronounced sentiment of Chinese nationalism expressed among the participants coming from both mainland China and the Chinese diaspora in North America. Presentations and discussions at the conference stressed the great importance of China in both the world political economy and global evangelism as well as the goal and mission of the Chinese to bring the Gospel to the Islamic Middle East and eventually back to Jerusalem. There was even a world map showing the mission route from China to Jerusalem, and conference participants conducted collective, simultaneous prayers in front of the map. The phrase “God really wants to use China” kept cropping up in spirit-filled meeting sessions, and some proclaimed that it is till the moment when this global Chinese mission is accomplished that China will become the most respectable nation in the world. This clearly resonates with the official rhetoric of "reclaiming China's rightful place in the world” (chongxin yiliyu shijieminzuzhilin).

It is noteworthy that there are striking similarities between urban Christian elites in Wenzhou and Pentecostal leaders worldwide in their positive attitude toward the use of secular resources and networks in church ministry and mission work. Wenzhou Christian entrepreneurs share a general consensus that compared with other Chinese Christian groups (i.e. the underground house church, the TSPM church, the rural church or urban Christian intellectuals) they have the greatest advantage in fulfilling this great mission given their economic power and the existing global Wenzhou business network, all of which are, in their view, preconditioned by God. As one young boss put it, characteristically, “God has used economic reforms and opening-up and our entrepreneurship initiatives (chuangye) to set up a complete business network, it is a global network, not just a nation-wide one. The Chinese church wants to undertake the great mission of returning the Gospel back to Jerusalem, and it 
needs to depend on Wenzhou's people networks (renmai). Wenzhou people are all over the world, and Wenzhou people must play the bellwether role (in this missionary endeavor).” Another boss echoed him in more succinct language when commenting on the world evangelistic map, “The world looks at China, China looks at Wenzhou, and Wenzhou looks at our Christian professionals.” As an expression of their strong sense of burden for the world mission, the passionate and assertive tone in which these Christian bosses made such statement is truly impressive. This form of self-promotion can also be found among the Wenzhou Christian diaspora, in which migrant merchants link Wenzhou's economic success with its role in its world mission (see Cao 2013).

Sometimes, Wenzhou Christian bosses' strong sense of burden for the world mission can stir their transnational imagination about a Wenzhou-led global Chinese mission movement. Popular media representations of Wenzhou people’s global business outreach help feed such imagination or fantasy. Wenzhou bosses have caught much Chinese media attention for their conspicuous consumption and bold investment projects worldwide. In early June, 2006, almost all the major Chinese news media agencies covered the purchase of a state-owned TV network in the United Arab Emirates (UAE) by a Wenzhou businessman named Wang Weisheng. $<<$ The sources within the parentheses were not found with References and therefore deleted. To be included, supply full information for them, including author names, dates, article titles in English, and source info. Agree to delete $>>$ Wang is a middle-aged garment factory boss and the vice head of the Wenzhou Chamber of Commerce in the UAE. His new TV network is expected to reach 400 million viewers in Arabic-speaking Middle East and North Africa and supposedly serve as a business information bridge for Chinese enterprises to enter the large market there. While many other Chinese treat Wang's tale as another case of China's rising overall national strength or just another example of Wenzhou businessmen's boldness and theatricality, urban Christian elites 
in Wenzhou perceived and interpreted this event beyond the boundaries of state approved narratives. As a young boss, who was a main organizer of the aforementioned Christian entrepreneurs' fellowship, $<<$ Name? Source? $>>$ states in a proposal prepared for the fellowship, with a tone similar to that of the Chinese state civilizing project: Wang Weisheng of Wenzhou city has bought an Arab state-owned TV network and renamed it as 'Alibaba Business Satellite TV.' It will start broadcasting on August 1st. The Christian churches have great concerns about the 'Arab world' and have used various methods of proselytizing there. But we still have not seen any 'great action.' Many missionaries have been sent to the Arab world and a great price has been paid. When we ask for people's commitment to proselytizing the Arab world, we cannot forget discussing issues of strategy and the feasibility of the methods. When it has become a common consensus to proselytize with a secular job and to serve God in the business field, we should place more emphasis on international scope, global arrangement, wide participation and deep impact! Maybe we hope Wang Weisheng is a Christian. Or maybe we should do something for this or reflect on this. Anyway, Wenzhou people and the Wenzhou chamber of commerce will work together to create more miracles! Maybe God is using some things to challenge and inspire us on our strategies and skills of proselytizing! Wenzhou people’s footprints have covered the entire world. Wenzhou business enterprises and Wenzhou chambers of commerce can be found everywhere across the globe. All of this can be resources for a transfer station of the "returning the Gospel to Jerusalem" mission. Have these resources been integrated into the strategic plan for proselytizing? Eighty percent of overseas Chinese reside in Southeast Asia. How to use their bilingual background to build a bridge of proselytizing is a key point. There are many channels and resources for Wenzhou 
people to utilize. It will attract great attention and will be highly expected if we can 'create a model' in a global age of proselytizing.

This statement reflects ambitions shared by many Wenzhou Christian bosses who want to market their Chinese model of evangelization that is expected to have deep impact on a global scale. Interestingly, the tale of a non-Christian Wenzhou businessman gives Wenzhou Christian bosses much space for anticipation and imagination about how to strategically bring the Gospel back to Jerusalem. It also reinforces their leadership role in this great civilizing mission. This envisaged use of mass media to conduct global mission outreach reflects the rise of media savvy male leadership in the local church, which is an important feature of the worldwide Pentecostal development—churches' able use of modern communication and entrepreneurial tools (see Anderson et. al. 2010).

Wenzhou Christian bosses employ the discourse on returning the Gospel to Jerusalem to place their business ambitions in a larger framework. It also produces legitimacy to their charismatic authority in the larger Chinese Christian community. The development of this particular discursive community of Christian entrepreneurs has occurred along with the mushrooming of new churches and fellowship organizations specially targeting local businesspeople. However, based around a few charismatic leaders, this pattern of church development is highly vulnerable to schism, and the newly established churches and fellowship groups have been accused by more established local churches for stealing sheep from them.

\section{Elite Celebrating the Maoist Revolutionary Legacy and a Postsocialist Market Modernity}

Brother Zhu, a middle-aged garment factory boss, is a founder of a new local Christian businessmen’s fellowship modeled on the U.S.-based Pentecostal group, Full Gospel Businessmen’s Fellowship International. As a charismatic local Christian leader, he passionately shared his grand visions from God in various fellowship meetings and 
dramatically drew parallels between his envisioned global mission of evangelization and Mao Zedong's revolutionary strategy. Zhu announced that his aim is to build Wenzhou as the spiritual Yan'an (shuling de yan'an, where Yan'an is China's communist revolutionary holy site) in China: “Wenzhou is like a holy land (jiaohui shengdi), China’s Jerusalem, like Mao Zedong’s Yan’an. Only a spiritual Yan’an can (spiritually) liberate the whole China.” Impressed and inspired by South Korea’s world’s largest church, Yoido Full Gospel Church that was founded by Pentecostal pastor Yonggi Cho, he became convinced that Korea's big church project triggered its spiritual revival and thus has been an avid advocate for a local megachurch project. In contrast to the older generation of house church leaders who hold strong antistate emotions, he believes that "God has used atheism to clear the field for evangelization, and only our professionals have the legitimate identity to ignite the fire of renewal in China and can carry the burden of returning the Gospel back to Jerusalem” because they “represent the house church, represent the entrepreneurs, and represent the TSPM. Neither the TSPM nor the house church can do great things. (State-ordained) Pastors cannot even preach across provincial borders.” He apparently has paraphrased the Communist Party’s slogan of “Three Represents” (san'ge daibiao, i.e., the Chinese Communist Party always represents the development needs of China's advancing productivity, the direction of China's advancing culture, and the fundamental interests of the Chinese people). ${ }^{13}$

While male lay leaders like Brother Zhu can draw on their rich social experiences and official state rhetoric such as the Three Represents in the church, as well as powerful metaphors such as the notions of "spiritual Yan'an” and "Jerusalem” in their competition for spiritual leadership, they have difficulty directly translating market rationality into charismatic power without the process of spiritualization, embedding business development in a spiritualized framework. The envisaged project of returning the Gospel back to Jerusalem 
can be considered as an example of this spiritual nationalism, exemplifying the elite males' attempts to discursively construct an elite mode of Chinese spirituality in tune with both state and capitalist modernities in order to lead the global Chinese Christian civilizing project. This prophetic practice also reveals a Pentecostal undercurrent behind the Christian resurgence in the era of post-Mao state-engineered modernization and globalization. Like spiritually experienced Christian women, these elite male Christians make predictions that certain things will happen in the future. Being able to articulate prophetic visions is considered an important and valued spiritual gift in the church community.

The fervent pursuit of market modernity in Chinese society has reconfigured the dynamics of Christian development that has its Pentecostal spiritual origin. The Wenzhou church’s linking of business with mission in both discourse and practice helps to build a bridge between the once-marginalized and victimized Chinese Christianity and the society at large, particularly in the context of what the reformist Chinese state has formulated as “economic development is the fundamental principle.” Wenzhou Christians, both men and women, accept the spiritual significance of submitting to the Holy Spirit. But there seems to be significant gender differences in understanding the working of the Holy Spirit and how to realize the ideal of being guided and empowered by the Holy Spirit. In light of the declining legitimacy of the charismatic movement (often associated with elderly lay women) in the context of rationalized market modernity, Wenzhou Christian businessmen exercise charismatic authority by combining a business-friendly prosperity theology with highly nationalistic visions. A transitional spiritual market economy (lingxing de shichangjingji) has frequently been brought up in the conversations among these business people. In this spiritual market economy, the TSPM is perceived as still abiding by the rules of a highly planned model of church development and the house church as operating like the tail of capitalism (ziben zhuyi de weiba), bearing the stigma under state socialism. For Christian businesspeople, 
their church development plan goes with Deng Xiaoping's reform that has transformed a planned economy to a market one. According to these ambitious lay leaders, it is in the transition period filled with political uncertainties and policy ambiguities that there exists an unprecedented strategic opportunity for church growth. One was prompted to ask rhetorically, "If we miss it, how can we report to God (xiang shen jiaodai)?”

Discussions will continue on how to get a head start in the perceived emerging spiritual market economy. It perhaps will not matter as to whether there will be a consensus reached among this elite group of Chinese believers. What is important is that they have derived power, legitimacy, significance, and inspiration by drawing metaphorical parallels between China's miraculous economic development and the spiritual growth of the Wenzhou church, between their personal business success and their rising status in the church, and between China’s state capitalism and an indigenous Chinese spiritual market economy.

However, it would be unfair to approach their religiosity simply in terms of a strategy to achieve secular success and distinction. In fact, they understand market success and failure as inextricably related to their status in the moral, spiritual sphere. One Christian businessman commented on this spiritual worldview, saying characteristically, Satan is going after and feeding on souls. Many entrepreneurs, including Christian ones, possess evil spirits. This is especially reflected on their extramarital affairs. They don’t know they need to pray. We need supernatural power to get things done so that we can have passion. Without engagement with the spiritual realm people will become mediocre.

These elite believers construct their charismatic power and present themselves as God's chosen people by spiritualizing their socioeconomic success and status, differentiating themselves from other Chinese Christian groups, and claiming spiritual authority based on a unique vision from God. Shaped by the interests of the upwardly mobile class, this elite mode 
of Christianity involves interlinked processes of differentiation, privilege building, and fierce contestation in the spiritual sphere.

\section{Conclusion}

The intersection of elite male religiosity and Christian nationalism as portrayed in this study sheds new light on China's shifting church-state relations. There has been a mutually constitutive engagement between $<<$ Changes correct? The meaning of "constitution" is unclear. This is the correct term in the field $>>$ Christianity and the state in contemporary China in both discourse and reality. This aspect of church-state relationship has not been adequately addressed and appreciated either in academic research or in journalist accounts that tend to overuse terms like "state persecution” and “Christian resistance.” Nevertheless, several recent studies have explored the convergence of state ideology and Christian faith, which are conducted mainly in the context of the relationship between the state and the socalled official church. For example, on the Christian side, Ryan Dunch (2008) has discussed the compatibility between Christian adherence and Chinese patriotism by focusing on Christianity’s “adaptation to socialism” as shown in the theological reconstruction movement led by Bishop Ding Guangxun. Focusing on the state's side of the story, Gerda Wielander (2011) shows that the Chinese state has adopted the Christian notion of love in building a "harmonious society." In this ethnographic case study, I demonstrate how this mutual relationship unfolds at the local grassroots level by examining how affluent Chinese house Christians engage state and market modernities in spiritual and moral terms. In particular, I suggest that there exists a grassroots Christian project of spiritual nationalism that involves a redemptive process in which elite Chinese Christians seek to address and overcome victimization and suffering inflicted by secular state modernity in a positively spiritual way (or, in their own terms, by repaying China's gospel debts to missionary sending Western nations). ${ }^{14}$ 
At the beginning of the twenty-first century, Christianity has become a fully indigenous religion for many Chinese believers as shown in the prophetic practice of formulating God's China vision. This God-given vision is both reflective and constitutive of an elite businessmen-led Christianity in coastal China. Backed by their recent experiences and memories of state-led spectacular economic modernization and shaped by the values of their social class, urban elite male Christians often show willingness to embrace state categories and express contempt for the lack of textual knowledge and greater social concerns among lay women and elderly members. Inspired by nationalistic native Pentecostal leaders in the early twentieth century, their prophetic vision is that China will eventually rule the world not only in economic terms, but also in the spiritual realm, and China will transform from a traditional missionary receiving nation to a glorious missionary sending nation. While the early indigenous church movements were never encapsulated in Chinese nationalism owing to their Christian conviction being equated with national disloyalty under Mao, post-Mao Christian development has come to be closely connected to national memories and nationalist imagination, thus countering the Chinese party-state's insistence on secular nationalism. ${ }^{15}$ As an alternative form of nationalism, spiritual nationalism is both fostered and regulated by the secular nation state. In the current political context of encouraging religion to adapt to socialism, Chinese Christians can express religious passion in an emotionally and publicly nationalist way while their missionary zeal and vision simultaneously extend beyond national boundaries. The nationalist project of reclaiming China's rightful place in the world has, to a large extent, informed the way local church leaders position the Chinese church and themselves in the global Christian movement.

In reform-era coastal China, the elderly women-dominated rural charismatic form of Christianity has gradually become subdued by an elite male-centered one in the context of marketization in which people are driven to succeed economically and increasingly embrace 
rationalization and an increased individualization and privatization of spirituality. New urban Chinese churches in advanced coastal regions are characterized by elite male leadership, a conservative theology that avoids political activism and an eagerness to take part in nation building. Their concern with developing an individuated, highly autonomous Chinese spirituality distinguishes them from politicized Beijing intellectual house churches that advocate religious freedom in the public sphere. As China’s integration into the global capitalist economy intensifies, this upwardly mobile urban class of believers will continue to be empowered to reconfigure the power relations of the Chinese church. This transformation has been greatly shaped by their diverse commercial experiences, their contact with likeminded overseas Chinese missionaries who likewise champion the notion of a global Chinese Christian mission, and their increased exposure to state-run public education and national media that subject them to the hegemonic state discourse of modernity and nation-building. ${ }^{16}$ It may well be that participants in this emerging urban elite sector of Chinese Christianity will increasingly place more emphasis on promoting individual spiritual growth and moral citizenship against the backdrop of a perceived moral and spiritual vacuum in China.

As shown in the Wenzhou case, China’s current Christian revival is not a monolithic religious phenomenon. In rapidly urbanizing areas, practicing Christian faith often involves intertwined social religious dynamics and processes such as linking up with the Western track, discovering national identity, acquiring official recognition, fulfilling moral duty, displaying elite masculinity, seeking cultural legitimacy, and gaining access to social resources and networks. This study adds complexity to our understanding of the role Christianity plays in stratified modern Chinese social life by portraying how some advantaged Christians have, wittingly or unwittingly, blended religious faith with nationalist emotions and ideas in spiritual and moral practices to create an elite mode of Christianity in China and in the world. The fact that our empirical knowledge of Chinese Christianity has been relatively limited 
compared with that of Chinese Buddhism, Daoism, and popular religion is, to a large extent, due to scholars' long-held, undeclared assumptions about what a Christian is and what Christianity means, based primarily on observations and understandings of the Western Christian experience and to a lack of serious attention to cultural, historical, and geographical contingencies of religion. Compared to Beijing Shouwang Church’s zealous advocacy of Christian rights in open defiance of the state's regulation of religious affairs, Wenzhou's Christian businesspeople would appear much less religiously orthodox for their upholding state norms, patriotic citizenship and a strong sense of global Chineseness (see Cao 2013). On the conceptual level, the significance of the Wenzhou story is that we need to eschew the tendency to make sweeping statements on Chinese Christianity and its relation to the state, and recognize that Chinese Christians are agents embedded in local structures of power relations informed by various historical events and memories and that they act with not just religious conscience but diverse cultural meanings. This is also where empirical research on Chinese Christianity may begin to contribute to understanding larger processes of sociocultural change in contemporary China.

\section{Notes}

1. “Three-Self” (sanzi) refers to self-administration (zizhi), self-support (ziyang), and selfpropagation (zichuan). The churches registered with the TSPM movement are often known as TSPM churches (sanji jiaohui) or official churches (guanfang jiaohui), while those unregistered are called house churches (jiating jaohui).

2. For a brief discussion of Christianity's relationship and interaction with nationalism, see van der Veer (2010) and compare to Xue (2005). $<<$ Changes correct? yes $>>$ Writing on modern Chinese Buddhist nationalism, Xue Yu has examined the simultaneous development of Buddhism and national awakening in the Second World War and highlighted the Buddhist 
struggle for a new national foothold in a politically unstable China under Japanese military domination and occupation.

3. Despite this distinction the Pentecostal practice of faith healing can be found in both sectors of the Chinese church. Some church historians have argued that most Chinese Christians are Pentecostal in a broader theological sense (see, e.g., Oblau 2005).

4. My discussion of Wenzhou Christianity in this paper draws from my fieldwork research conducted in Wenzhou between 2005 and 2011. For a more complete picture of contemporary Wenzhou Christianity, see Cao (2011).

5. Hong Kong-based American Pentecostal missionary Dennis Balcombe seems to have had a profound impact on the house church network in Henan (see Aikman 2003, 271-275).

6. See Bays (2003) for a discussion of the Pentecostal legacy of Chinese independent churches founded early in the twentieth century.

7. The official TSPM churches also organize spiritual cultivation meetings and do not deny the truthfulness of healing miracles.

8. For a discussion of Eastern Lightning's relationship to the state and Protestant communities, see Dunn (2009).

9. The campaign of December 2000 to dismantle unregistered temples and churches in Wenzhou should be seen as a sporadic incident that the post-Mao state uses to make itself visible in local society, rather than a manifestation of a new trend in state religious governance. There are several versions of the story. What is clear is that it was not a local government-initiated campaign but a sudden political measure imposed by the higher provincial-level state. I was told by Wenzhou church leaders that the head of Wenzhou's Religious Affairs Bureau was removed from his post after the campaign as a gesture of apology for the destruction, and the municipal government privately made compensation for some affected churches, and many of the churches that were demolished during the campaign 
soon acquired new sites through the property market.

10. Reverand J. Hudson Taylor was one of the most influential Western missionaries in

China. His autobiography, To China with Love, was translated into Chinese and published in 2004 by People’s Daily Press in Beijing. This has incurred much speculation on the Chinese government's possible reappraisal of the early Western missionary endeavor in China.

11. The Jesus Family, a major Pentecostal group originated in Shandong Province, first coined the vision in the 1920s, and a splinter group called the Northwest Spirit Movement sent their small evangelistic band to Xinjiang in an attempt to carry out the vision but apparently failed. For details of the movement, see www.backtojerusalem.com.

12. Interestingly, during my fieldwork, no Wenzhou Christian women ever mentioned this China vision to me. Discussions on the global Chinese mission were dominated by young and middle-aged businessmen, a fact pointing to the close connection between masculinity and elite nationalism.

13. These Christian businessmen's familiarity with state rhetoric largely results from their being regular viewers of the national news program on China's central television (CCTV). Wenzhou businesspeople watch national news to keep updated on policy change that may affect their business and investment practices.

14. Mayfair Yang's (2008) edited volume provides a rich collection of case studies showing how radical state modernization and secularization efforts have demonized and largely weakened China’s once rich religious life.

15. However, secular nationalism is not a Chinese communist invention but a legacy inherited from the Kuomintang regime in the Republican period. See Nedostup (2010) for a careful historical investigation of the Kuomintang's secularizing project and state-building efforts during the Nanjing decade.

16. See Kipnis (2012) for a detailed analysis of how China’s educational standardization and 
national internet system have constructed commonalities among Chinese people from diverse backgrounds and locations, which are central to contemporary Chinese nation building.

References $<<$ Add “(in Chinese)” at the end of any of the references that are in Chinese, not English. See, for example, National Bureau of Statistics (2005) below for correct usage. $>>$

Aikman, David. 2003. Jesus in Beijing: How Christianity Is Transforming China and Changing the Global Balance of Power. Washington, DC: Henry Regnery. Anderson, Allan, Michael Bergunder, André Droogers, and Cornelis van der Laan (eds.). 2010. Studying Global Pentecostalism: Theories and Methods. Berkeley: University of California Press.

Bays, Daniel H. 1993. “Christian Revival in China: 1900-1937.” Pp. 167-169 in Modern Christian Revivals, edited by Edith L. Blumhofer and Randall Balmer. Champaign, IL: University of Illinois Press.

-1995. "Indigenous Protestant Churches in China, 1900-1937: A Pentecostal Case Study.” Pp. 124-143 in Indigenous Responses to Western Christianity, edited by Steven Kaplan. New York: NYU Press.

.2003. “Chinese Protestant Christianity Today.” The China Quarterly 174: 488-504.

Cao, Nanlai. 2009. "Raising the Quality of Belief: Suzhi and the Production of an Elite Protestantism.” China Perspectives 4: 54-65.

— 2011. Constructing China’s Jerusalem: Christians, Power, and Place in Contemporary Wenzhou. Stanford: Stanford University Press.

—_. 2013. "Renegotiating Locality and Morality in a Chinese Religious Diaspora: Wenzhou Christian Merchants in Paris, France.” The Asia Pacific Journal of Anthropology 14(1). Forthcoming in January $<<$ Can you update the information?>> 
Deng, Zhaoming. 2005. “Indigenous Chinese Pentecostal Denominations.” Pp. 437-466 in Asian and Pentecostal: The Charismatic Face of Christianity in Asia, edited by Allan Anderson and Edmond Tang. London: Regnum Books International.

Dunch, Ryan. 2001a. "Protestant Christianity in China Today: Fragile, Fragmented, Flourishing.” Pp. 195-216 in China and Christianity: Burdened Past, Hopeful Future, edited by S. Uhalley Jr. and X. Wu. Armonk, NY: M.E. Sharpe.

—. 2001b. Fuzhou Protestants and the Making of a Modern China, 1857-1927. New Haven and London: Yale University Press.

_ 2008. "Christianity and 'Adaptation to Socialism.'” Pp. 155-178 in Chinese Religiosities: Afflictions of Modernity and State Formation, edited by Mayfair Yang. Berkeley: University of California Press.

Dunn, Emily C. 2009. ““Cult,’ Church, and the CCP: Introducing Eastern Lightning.” Modern China 35 (1): 96-119.

En, Hui. 2005. “Comments on Spiritual Cultivation Meetings.” Tianfeng 9:18-19 (in Chinese).

Goossaert, Vincent, and David A. Palmer. 2011. The Religious Question in Modern China. Chicago: University of Chicago Press.

Hunter, Alan, and Kim-Kwong Chan. 1993. Protestantism in Contemporary China. Cambridge: Cambridge University Press.

Jin, Ze, and Qiu Yonghui (eds.). 2010. “An In-House Questionnaire Survey on Christianity in China.” Pp. 190-212 in Annual Report on China’s Religions. Beijing: Social Sciences Academic Press (in Chinese).

Kao, Chen-Yang. 2009. “The Cultural Revolution and the Emergence of Pentecostal-Style Protestantism in China.” Journal of Contemporary Religion 24(2): 171-188. 
Kipnis, Andrew. 2012. “Constructing Commonality: Standarization and Modernization in Chinese Nation-Building.” Journal of Asian Studies 71(3): 731-755.

Lee, Joseph Tse-Hei. 2005. "Watchman Nee and the Little Flock Movement in Maoist China.” Church History 74: 68-96.

Lian, Xi. 2010. Redeemed by Fire: The Rise of Popular Christianity in Modern China. New Haven, CT: Yale University Press.

Lutz, Jessie G. 1988. Chinese Politics and Christian Missions: The Anti-Christian Movements of 1920-1928. Norte Dame: Cross Cultural Publications.

Madsen, Richard. 1998. China's Catholics: Tragedy and Hope in an Emerging Civil Society. Berkeley: University of California Press.

—. 2010. “Chinese Christianity: Indigenization and Conflict.” Pp. 239-260 in Chinese Society: Change, Conflict and Resistance, edited by Elizabeth J. Perry and Mark Selden. New York: Routledge.

Nedostup, Rebecca. 2010. Superstitious Regimes: Religion and the Politics of Chinese Modernity. Cambridge, MA: Harvard University Asia Center.

Nyíri, Pál. 2006. “The Yellow Man’s Burden: Chinese Migrants on a Civilizing Mission.” The China Journal 56: 83-107.

Oblau, Gotthard. 2005. "Pentecostal by Default? Contemporary Christianity in China.” Pp. 411-436 in Asian and Pentecostal: The Charismatic Face of Christianity in Asia, edited by Allan Anderson and Edmond Tang. London: Regnum Books International. van der Veer, Peter. 2010. “Nationalism and Christianity.” Pp. 855-856 in The Cambridge Dictionary of Christianity, edited by Daniel Patte. Cambridge: Cambridge University Press.

Wenzhou Bureau of Statistics. 2005. Wenzhou Statistical Yearbook. Beijing: Zhongguo tongji chubanshe (in Chinese). $<<$ Changes correct? $>>$ 
Wesley, Luke. 2004. “Is Chinese Church Predominately Pentecostal?” Asian Journal of Pentecostal Studies 7(2): 225-254.

Wielander, Gerda. 2009. “Bridging the Gap? An Investigation of Beijing Intellectual House Church Activities and Their Implications for China’s Democratization.” Journal of Contemporary China 18(62): 849-864.

—_. 2011. "Beyond Repression and Resistance—Christian Love and China’s Harmonious Society.” The China Journal 65: 119-138.

Xue, $<<$ Changed to match the citation and Web search. $>>$ Yu. 2005. Buddhism, War, and Nationalism: Chinese Monks in the Struggle Against Japanese Aggressions, 19311945. New York and London: Routledge.

Yang, Mayfair (ed.). 2008. Chinese Religiosities: Afflictions of Modernity and State Formation. Berkeley: University of California Press.

About the Author: Nanlai Cao is an anthropologist currently affiliated with the Hong Kong Institute for the Humanities and Social Sciences, University of Hong Kong. He holds a bachelor's degree in sociology from Beijing University, an M.A. in sociology from Fordham University, and a Ph.D. in anthropology from The Australian National University. His ethnographic work on Chinese Christians has appeared in such journals as The China Journal, China Perspectives/Perspectives Chinoises, and Sociology of Religion: A Quarterly Review. Drawing on nearly two years of fieldwork in Wenzhou city in coastal southeast China, his first book is titled Constructing China's Jerusalem: Christians, Power, and Place in Contemporary Wenzhou (Stanford University Press, 2011). His current research explores the religious and social aspects of China's reform-era globalization by focusing on the global Wenzhou diaspora as an ethnographic case study. 